\title{
MARTIN MÜLLER
}

Przełożyła ANNA PIEKARSKA

W poszukiwaniu Globalnego Wschodu: Myślenie między Północą a Południem

Od zakończenia zimnej wojny dzielenie świata na Globalną Północ i Globalne Południe stało się ogólnie przyjętym sposobem myślenia o globalnej różnicy. Ta opozycja binarna wymazuje jednak istnienie tego, co nazywam Globalnym Wschodem - krajów i społeczeństw, które zajmują pozycję pośrednią, pomiędzy Północą a Południem. Niniejszy artykuł problematyzuje geopolitykę wiedzy powstałą wskutek wykluczenia Globalnego Wschodu, nie tylko z Globalnej Północy i Południa, ale z koncepcji globalności w ogóle. Argumentuje, że w celu odzyskania Globalnego Wschodu dla nauki musimy wykorzystać stanowisko strategicznego esencjalizmu. Analizuje w tym kontekście globalne powiązania kryjące się za szklankami z fazowanego szkła z IKEI, by pokazać konieczność pomyślenia Globalnego Wschodu w sercu globalnych stosunków, a nie poza nimi. Myślenie o Globalnym Wschodzie jako przestrzeni liminalnej problematyzuje pojęcia Północy i Południa na rzecz bardziej inkluzywnego, ale również mniej dookreślonego myślenia teoretycznego.

Słowa kluczowe: Globalna Północ, Globalne Południe, Drugi Świat, postkolonializm, postsocjalizm, postkomunizm, geopolityka wiedzy 


\section{Wprowadzenie: tracąc Wschód}

Wyobraź sobie na moment „Globalną Północ”. Jak większość osób zapewne pomyślisz o krajach Ameryki Północnej i Europy Zachodniej, być może jeszcze o Japonii i Australii - bogatych państwach i wielkich centrach metropolitalnych. A co w przypadku Globalnego Południa? Na myśl przyjdzie ci zapewne Ameryka Łacińska i Afryka, podobnie jak znaczna część Azji. Miejsca, w których ludzie nie cieszą się tymi samymi przywilejami co ci z Północy. Świat widziany w ten sposób, oczyma naszej wyobraźni, wydaje się kompletny, jednak nic bardziej mylnego. Rzecz ma się wręcz przeciwnie, opozycja binarna Północy i Południa wytwarza bowiem ślepą plamkę: pomija wszystkie te społeczeństwa, które lokują się gdzieś pomiędzy nimi - zbyt zamożne, by przypisać je do Południa i jednocześnie zbyt biedne, by zaklasyfikować je do Północy. Ta ślepa plamka nie jest też wcale mała: obejmuje wszystkie te społeczeństwa, które wzięły udział w najbardziej brzemiennym w skutkach globalnym eksperymencie w XX wieku - budowie komunizmu ${ }^{1}$. Ten „Globalny Wschód”, jak będziemy się do niego odnosić w niniejszym artykule, jest zawieszony w swoistej strefie cienia, gdzieś pomiędzy Globalną Północą a Globalnym Południem, nie należąc jednocześnie w pełni do żadnego z nich. Dlatego też naszym zadaniem będzie wydobycie go na światło dzienne.

Rozróżnienie na bogatszą i potężną Globalną Północ oraz biedniejsze i mniej potężne Globalne Południe jest współcześnie być może najbardziej rozpowszechnionym sposobem kategoryzacji świata i myślenia o globalnych różnicach. Rozróżnienie to stało się nie tylko standardem w badaniach akademickich, dając początek kilku czasopismom naukowym, licznym centrom badawczym i setkom monografii, które w swoich tytułach i nazwach odwołują się do Globalnego Południa. Zaczęło również wkradać się do słownika naukowców, aktywistów i, w coraz większym stopniu, do debat politycznych i eksperckich. Przykładowo w debatach dotyczących zmiany klimatycznej podział Północ-Południe stał się wiodącym określeniem na ujmowanie różnic politycznych odnośnie tego, jak uporać się z globalnym ociepleniem. Uprawomocniło go dodatkowo ponowne odkrycie ubóstwa na początku ostatniego tysiąclecia przez Organizację Narodów Zjednoczonych, która potraktowała je jako swoje wyzwanie w ramach Milenijnych Celów Rozwoju.

1 Zgodnie z przyjętym powszechnie rozróżnieniem używam słowa „komunizm” w odniesieniu do ideologii, a „socjalizm” - do rzeczywistości społeczno-politycznej. 
Globalna Północ i Południe oznaczają dziś nie tyle obszary geograficzne, ale przede wszystkim projekt polityczny i epistemologiczny: odejście od języka postępu i teleologicznego rozwoju, który przez dekady charakteryzował i nadal charakteryzuje stosunek Globalnej Północy do Południa; reorientację produkcji wiedzy, czyli rezygnację z uniwersalizmu i europocentryzmu Północy na rzecz dowartościowania wielości praktyk wiedzy istniejących w Globalnym Południu; polityczną inspirację dla przekształcenia globalnej polityki tak, by pozwolić przemówić bardziej marginalnym narodom (Dirlik 2007; Mignolo 2011). Jako takie Globalne Południe jest częścią i elementem postkolonialnego projektu oddawania głosu podporządkowanemu innemu (Spivak 2010).

Upadek większości reżimów komunistycznych, tak zwanego Drugiego Świata, pomiędzy rokiem 1989 i 1992 nie wpłynął na podział Północ-Południe, wręcz przeciwnie - uprawomocnił go. W koncepcji końca historii Fukuyamy (2009) rozróżnienie na bogatych i biednych, to jest Północ i Południe, utrzymało się, natomiast opozycja między kapitalizmem a komunizmem wyparowała. Wraz ze zniknięciem komunistycznego Innego zniknął również ideologiczny podział na Zachód-Wschód. „Równolegle z rozpadem Związku Radzieckiego, kategoria Drugiego Świata stała się mniej użyteczna (...) Nadszedł czas na nowy, uproszczony podział. Pierwszy Świat stał się Północa, a Trzeci Świat zamienił się w Południe" (Reuveny i Thompson 2007, 557). Ale co z Drugim Światem?

Wschód, zamiast stać się częścią Północy lub Południa, odszedł w zapomnienie. Posługuje się tu pojęciem „Wschodu” jako skrótowcem odnoszącym się nie tyle do regionu geograficznego, co do przestrzeni epistemicznej - przestrzeni liminalnej między Północą a Południem. Chociaż tak rozumiany Wschód postrzegam przez pryzmat doświadczenia dawnego Drugiego Świata, samo pojęcie Wschodu jako Globalnego Wschodu nie ogranicza się wyłącznie do niego, ale może także, a nawet powinno obejmować inne społeczeństwa liminalne. Upadek politycznego projektu Drugiego Świata - komunizmu - wymazał Wschód z globalnej mapy, a jakakolwiek wyjątkowość ponad siedemdziesięcioletnich rządów komunistycznych zniknęła. Wschód jest zbyt zamożny, by móc uznać go za prawowitą część Południa i równocześnie zbyt biedny, by dołączyć do Północy. Jest zbyt silny, by uznać go za peryferie, a zarazem zbyt słaby, by być częścią centrum. Stosunki władzy biegną w każdą stronę. Na Wschód składają się zarówno kolonizatorzy i kolonie, agresorzy i ofiary, część krajów pełniła zresztą jednocześnie obie te role (Tlostanova 2008). Innymi słowy, Wschód nam się wymyka, trudno go skategoryzować.

W globalnej cyrkulacji znaków Wschód jest znacznie mniej czytelny niż Globalne Południe, gdzie kolonializm stworzył wspólnotę języków,

Upadek większości reżimów komunistycznych, tak zwanego Drugiego Świata, pomiędzy rokiem 1989 i 1992 nie wpłynął na podział Północ-Południe, wręcz przeciwnie - uprawomocnił go. 
instytucji, systemów wiedzy i więzi społecznych. Uganda jest bardziej rozpoznawalna w globalnych centrach medialnych i naukowych niż Ukraina, Chile góruje w tej kwestii nad Czechami, a Laos jest bliższy od Łotwy. Vargas Llosa, García Márquez i Coetzee brzmią znajomo, natomiast Aleksijewicz, Müller i Szymborska wydają się obce. Cała ta szóstka to niedawni laureaci Nagrody Nobla w dziedzinie literatury.

Wschód doświadcza zatem podwójnego wykluczenia. Z jednej strony nie uważa się go za część Globalnego Południa. The Poorer Nations Vijaya Prashada (2013), jedna z najistotniejszych historii Globalnego Południa, nosi znamiona swojej geograficznej afiliacji na obwolucie: przedstawiona na niej mapa Globalnego Południa obejmuje Turcję, Argentynę i Chile, ale dla przykładu pomija Kirgistan, Mołdawie czy Ukrainę - wszystkie $\mathrm{z}$ nich istotnie uboższe od tych pierwszych. Prace przeglądowe na temat Globalnego Południa pomijają Globalny Wschód. An Everyday Geography of the Global South (Rigg 2007) składa się z 90 studiów przypadku w 36 krajach, z których żaden nie zalicza się jednak do Globalnego Wschodu. The Handbook on Cities in the Global South przyznaje przynajmniej, że „znaczna część Eurazji jest ignorowana (Parnell i Oldfield 2014, 3). Institutions of the Global South (Braveboy-Wagner 2009) ograniczają się do Azji, Afryki i Ameryki Łacińskiej. Ta cisza jest tym bardziej niepokojąca, że większość naukowców podkreśla płynność pojęcia Globalnego Południa, pozbawionego ostrych granic (Dirlik 2007; Roy i Crane 2015). Mimo to wydaje się ono nie dość płynne, by obejmować chociaż części dawnego Drugiego Świata.

Wschód jest jednak oddzielony również od Globalnej Północy. W pracach poświęconych globalnym miastom i światowym centrom, sercom demokracji i rynkowego kapitalizmu, Wschód pozostaje niemym świadkiem dyskusji. Położone na Wschodzie kraje być może są na drodze prowadzącej w północnym kierunku, ale jednocześnie wydają się uwięzione w nieustającym procesie przejścia do nieuchwytnej nowoczesności. Jako przedmiot północnoamerykańskiej i europejskiej mission civilisatrice Wschód definiuje się przez jego zacofanie, od stuleci nieodzowny wyróżnik Europy Wschodniej (Kovačević 2008; Neumann 1999; Todorova 2014; Wolff 2020). Pełnił on w związku z tym rolę Innego, dzięki któremu Europa Zachodnia od dawna wytwarzała narrację o swojej cywilizacji i postępie.

Niniejszy tekst jest krokiem w kierunku przywrócenia roli Wschodu jako ośrodka produkcji wiedzy i w tym sensie dotyczy globalnej geopolityki tej ostatniej. W tym celu ujmuje go jako Globalny Wschód - zarazem różny od reszty świata, a jednak z nim połączony; równy Północy i Południu, a nie wobec nich podrzędny. Ten epistemiczny wysiłek nie jest 
istotny wyłącznie dla ludzi żyjących w krajach Globalnego Wschodu, dla docenienia unikalności i powiązania ich doświadczeń, a także badaczy Globalnego Wschodu, którzy często nie wiedzą, jak umiejscowić przedmiot swoich badań w globalnej nauce, która dzieli świat na Północ i Południe.

Zadanie to jest jeszcze bardziej istotne z perspektywy myślenia teoretycznego. W epoce myślenia poza perspektywą europejską i amerykańską (Bhabha 2010; Chakrabarty 2011; Mbembe 2000) sprawne myślenie teoretyczne, a tym bardziej myślenie teoretyczne w kategoriach globalnych, nie może obyć się bez zrozumienia i głębokiego uznania dla zróżnicowania i powiązania rzeczywistości społecznych, do których z założenia się odnoszą. Myślenie o Globalnym Wschodzie jest być może jeszcze istotniejsze dla Globalnej Północy i Globalnego Południa, gdyż poważne potraktowanie tego pierwszego nie może obyć się bez zakwestionowania takich pewników jak zamożny i ubogi czy potężny i słaby, do których być może aż nadto się przywiązaliśmy. Odzyskanie Globalnego Wschodu oznacza myślenie z perspektywy szczeliny pomiędzy Północą a Południem - nie tylko na rzecz Wschodu, ale również Północy i Południa.

Niniejszy tekst stwarza warunki do myślenia o Globalnym Wschodzie w czterech krokach. W pierwszym analizuje „wschodniość” jako kłopotliwe położenie związane nie tyle z ulokowaniem go na marginesie, ale w szczelinach pomiędzy Północą a Południem. Tekst traktuje zatem wschodniość jako liminalną kondycję pośredniości - nie do końca Północy, nie do końca Południa - a nie jego położenie geograficzne. Ta pośredniość jest przyczyną ignorancji zarówno po stronie Północy, jak i Południa. Po drugie, artykuł pokazuje, dlaczego Wschód pozostaje niepoznawalny, ponieważ znajduje się poza obwodami i przewodami zachodniej architektury wiedzy. Po trzecie, postuluje konieczność strategicznej esencjalizacji Wschodu, która podkreśla jedność pomimo różnic pośredniej pozycji Wschodu i usiłuje odzyskać Wschód jako projekt polityczny. W końcu, dzięki myśleniu o nim jako znajdującym się pośród globalnych stosunków, a nie od nich odciętym, ukazuje, czemu Wschód jest i musi być Globalnym Wschodem. W ten sposób afirmuje otwartość Globalnego Wschodu przeciwko zewnętrznym i wewnętrznym próbom jego izolacji.

Kłopotliwe położenie wschodniości - nie do końca Północ, nie do końca Południe

Gdy uczę o Globalnym Wschodzie, moi studenci są zdziwieni, że w ogóle mogę interesować się tak nieciekawym miejscem. Brazylia jest seksowna, 
Kenia jest fajna, a Chiny dynamiczne - Wschód okazuje się jednak nudny. Poczułem ulgę, choć jednocześnie zakłopotanie, gdy okazało się, że nie jestem w tym doświadczeniu odosobniony. W swoim przeglądzie literackich odrębności Wschodu Mikanowski (2017, n.p.) wspomina, że „zna wybitnego badacza regionu, historyka prowadzącego kursowy przedmiot poświęcony historii Europy Wschodniej, który powiedział mu, że każdego roku musi odpowiadać na pytania studentów o to, czy ludzie są w ogóle zdolni do miłości i śmiechu w tym "szarym miejscu"”. Zapewne lepszym wyborem byłoby nauczanie o "Czarnym Lądzie”, przynajmniej doświadczyłbym nieco współczucia od dobroczyńców, a nie o „szarym miejscu”, które nie wywołuje żadnych emocji - terra incognita świata, gdzie Macedonia, Mołdawia, Czarnogóra i Molvanîa ${ }^{2}$ zlewają się w amorficzną masę.

Kłopotliwe położenie Wschodu cechuje podwójne wykluczenie: z uprzywilejowanej Globalnej Północy i z marginalizowanego Globalnego Południa. Nie jest to jednak zupełna Inność. Mamy tu raczej do czynienia z pół-innością (Tlostanova 2017), pół-orientalizmem (Wolff 2020). Wschód jest odmienny, ale trochę podobny, Inny, ale nie w pełni. Jest szarym miejscem i zarazem „szarą strefą” nieokreśloności (Knudsen i Frederksen 2015). Globalna Północ, często pod płaszczykiem „Europy”, pełni rolę teleologicznego horyzontu, wobec którego Wschód staje się nie-w-pełni Północą. Poszczególne państwa mogą dołączyć do Unii Europejskiej, ale subtelne dystynkcje habitusu eurokratów na brukselskich korytarzach władzy wciąż podkreślają różnice między Wschodem i Zachodem (Kuus 2014), podobnie jak rasizm, którego w Europie Zachodniej doświadczają imigranci z Europy Wschodniej (Nowicka 2017). Ludzie mogą uczestniczyć w europejskiej konsumpcji, jak w przypadku wszechobecnej „eurorenowacji” (evroremont) (Sgibnev 2015), a jednak nigdy nie stać się w pełni europejscy. Ta „wschodniość”, jak nazywa ją część badaczy (Kuus 2007; Zarycki 2014), była przed dekady, jeśli nie stulecia, wyznacznikiem Wschodu pomimo dołączenia do Unii Europejskiej, dekad wzrostu gospodarczego i powszechnej prywatyzacji i demokratyzacji.

Pod tym względem Wschód współdzieli wiele z postkolonialną kondycją bycia w „poczekalni historii” (Chakrabarty 2011, 10), dążenia do nowoczesności, w której mógłby uczestniczyć, ale tylko za łaskawym przyzwoleniem Europy, która rozciąga swoją mission civilisatrice i wszystko,

2 Molvanîa to fikcyjny kraj opisywany w parodystycznym przewodniku wykorzystującym Zachodnie stereotypy Wschodu (Cilauro, Gleisner i Sitch 2004). Zob. także stworzony przez Malcolma Bradbury'ego fikcyjny kraj Slaka w Europie Wschodniej (Bradbury 1986). 
co się z nią wiąże, na „Dziki Wschód” (Gille 2016; Horvat i Štiks 2012; Melegh 2006). Jeśli bowiem Wschód miałby kiedykolwiek wkroczyć do Europy, „wszystko już przewidziano, znaleziono, udowodniono, wykorzystano", by przywołać sławetne sformułowanie Fanona $(2020,133)^{3}$. Wschód pozostaje całością nie ze względu na jedność polityczną, wspólne więzi gospodarcze czy kulturę i tradycję (Hann et al. 2016) ani na wspólne doświadczenie socjalizmu (Müller 2019), ale raczej przez współdzielone poczucie jednoczesnej przynależności i różnicy w stosunku do amorficznej Europy.

Wschód można również interpretować na bardziej ekonomiczno-polityczną modłę, odczytywać go za pomocą trzypoziomowej teorii systemów-światów Immanuela Wallersteina (1979)4 . Obraz, który w ten sposób otrzymujemy, jest jednak nieco bardziej rozmazany. $\mathrm{O}$ ile dla Wallersteina (1976) państwa socjalistyczne zaliczały się wcześniej do krajów półperyferyjnych, o tyle sytuacja zmieniła się wraz z socjalistyczną implozją. Choć niektóre państwa centralnej Azji, południowego Kaukazu i południowo-wschodniej Europy prawdopodobnie zaliczają się dziś do peryferii, to większość państw członkowskich Unii Europejskiej z obszaru Europy Wschodniej zbliża się pod względem gospodarczym coraz bardziej do centrum. Taka jest przynajmniej diagnoza szeregu badaczy, którzy podjęli próbę współczesnego wykorzystania kategorii stworzonych przez Wallersteina (Babones i Babcicky 2011; Bradshaw 2001; Knox, Agnew i McCarthy 2014, 22). Te państwa, które pozostały półperyferiami jak Rosja czy Rumunia, należą do tej samej, dosyć heterogenicznej kategorii co inne kraje półperyferyjne, na przykład Grecja, Chile, Botswana i Wietnam. Analiza syste-

3 Oryginalne francuskie sformułowanie jest znacznie zwięźlejsze niż tłumaczenie: „tout est prévu, trouvé, prouvé, exploité” (Fanon 1952, 97).

4 Wallerstein proponuje trzypoziomową strukturę stratyfikacji dzielącą się na centrum, półperyferie i peryferie, co wynika z dwóch form procesów gospodarczych: zachodzących w centrum procesów wiążących się z wysokimi płacami, zaawansowaną technologią i zróżnicowaną strukturą produkcji oraz peryferyjnych procesów, z którymi wiążą się niskie płace, bardziej podstawowa technologia i prosta struktura produkcji. Wprowadzona przez niego pośrednia kategoria półperyferii nie jest po prostu gospodarczą mieszanką dwóch pozostałych kategorii, ale, co istotniejsze, posiada funkcję polityczną: zapewnia polityczną stabilność przez łagodzenie polaryzacji między centrum i peryferiami. „Można by stwierdzić, że gospodarka-świata mogłaby dobrze funkcjonować jako gospodarka bez półperyferii. Byłaby jednak w takim przypadku znacznie mnie stabilna" (Wallerstein 1979, 23). Zdaniem Wallersteina $(1979,69)$ dwie podstawowe cechy krajów pólperyferyjnych to protekcjonizm („wewnętrzny rynek dla krajowych produktów”) i upolitycznienie decyzji gospodarczych. 
mów-światów ukazuje tym samym pęknięty obraz Wschodu jako należącego częściowo do Północy, częściowo do Południa, a częściowo znajdującego się pomiędzy.

Chociaż Wschód jako połowiczny-Inny Zachodu zbliża się do postkolonialnej kondycji Południa, to nie jest włączony w południową walkę emancypacyjną. Nie jest do końca Północą, nie będąc do końca Południem. W podejmowanym wysiłku tworzenia zdekolonizowanej wiedzy i teoretycznego myślenia wychodzącego od Południa Wschód nie jest wspominany: nie wrzuca się go do jednego worka z Ameryką Łacińską, Azją i Afryką. Nic z tych rzeczy, po prostu nie jest częścią tego projektu. Nie jest to jednak zaskakujące, jeśli pod uwagę weźmiemy standardowe definicje Północy i Południa:

Podział na Północ i Południe jest przeważnie ujmowany jako podział społeczno-ekonomiczny i polityczny. Ogólnie rzecz biorąc, definicje Globalnej Północy obejmują Stany Zjednoczone, Kanadę, rozwinięte części Europy i Wschodnią Azję. Na Globalne Południe składają się Afryka, Ameryka Łacińska i rozwijające się państwa azjatyckie, włącznie z Bliskim Wschodem (Wikipedia, cyt. za: Mignolo 2014a, n.p.).

Ta definicja wyklucza Globalny Wschód, podobnie jak same próby myślenia teoretycznego wychodzącego od Południa. Nowatorska praca Raewyny Connell (2018), Teoria z globalnego Południa, lokuje Południe w Afryce, Ameryce Łacińskiej, Indiach i Iranie (dokładnie tych regionach, które pojawiają się w przytaczanej definicji). Theory from the South Jean i Johna Comaroffów (2011) przygląda się Afryce, natomiast New Geographies of Theory Ananyi Roy (2009) - Indiom.

Nieobecność Wschodu w projekcie Globalnego Południa jest uderzająca, choć może nie zaskakująca. Wynika ona w końcu z jego przejściowego statusu - pod względem społecznym, ekonomicznym i politycznym. Comaroff i Comaroff $(2011,46)$ zastanawiają się: „Po której stronie [Północy czy Południa] lokują się dla przykładu państwa dawnego ZSRR?”. Jako niegdysiejszy Drugi Świat wschodnie społeczeństwa nie organizowały się na szczytach w rodzaju Konferencji w Bandungu, by rozważyć problem trzeciej drogi między kapitalizmem a socjalizmem. Gdy podczas wydarzeń lat 1989-1992 upadł obóz socjalistyczny, wszystko wskazywało na to, że wraz z przejściem do kapitalizmu Wschód dołączy do Północy. Jednak pomimo ponad 25 lat, które minęły od tego upadku, przejście to pozostaje niedokończone, zarówno pod względem poziomu zamożności Północy, jak i pod względem tworzenia instytucji rynkowego kapitalizmu. Wschód ostatecznie skończył jako hybryda 
dziedzictwa socjalistycznego, neoliberalnego kapitalizmu i nieformalnych oraz patrymonialnych praktyk.

Kolonializm naznacza również Wschód, chociaż w inny sposób niż Południe. Kolonializm, być może najbardziej dystynktywny element Południa (Dirlik 2007), również pod względem znaczenia dla myślenia teoretycznego, na Wschodzie nie przebiega w prosty sposób. Wiele jego części doświadczyło kolejnych fal kolonizacji, za którymi stały Imperium Otomańskie, Cesarstwo Austro-Węgierskie czy Rosja i Związek Radziecki, a z każdym z nich wiązał się zresztą dość odmienny system dominacji. Narzucenie przez Zachód reform rynkowych w latach dziewięćdziesiątych XX wieku (Boycko, Shleifer i Vishny 1995) dołożyło kolejny stosunek podporządkowania do tych już istniejących.

Jeśli kolonizowany jest definiowany przez stosunek do kolonizatora (Fanon 2020), to Wschód posiada wiele tożsamości. Niektóre kraje były zarówno kolonizatorami, jak i koloniami. Madina Tlostanova (2008, 2011) problematyzuje tę pośrednią pozycję na przykładzie Rosji, która została obsadzona w podwójnej roli imperium kolonialnego (zarówno przed, jak i w trakcie istnienia Związku Radzieckiego) i podporząadkowanego Innego (Europy) - dlatego też nazywa ją podporządkowanym imperium. Jako taki Wschód zajmuje niewygodną pozycję pomiędzy w większości postkolonialnymi społeczeństwami Południa i centrami władzy na Północy. To z kolei sprawia, że relacja kolonizator/kolonizowany staje się w przypadku Wschodu wielopoziomowa, gdzie trudno jednoznacznie wskazać metropolię. Jeśli jesteś Bułgarem, gdzie znajduje się twoja metropolia? W Stambule, Moskwie, Brukseli czy może w Nowym Jorku?

Wreszcie, w przeciwieństwie do Południa ludzie nie dostrzegli we Wschodzie pobudek do współczucia, globalnego aktywizmu czy źródła alternatyw dla neoliberalizmu, zniszczeń środowiska naturalnego, polityki siły oraz niepohamowanego nacjonalizmu. Dawnemu sercu Reaganowskiego „imperium zła” brakuje moralnej wyższości podporząakowanego i pozbawionego praw obywatelskich, które napędza Globalne Południe - pomimo Euromajdanu, Rewolucji Róż, Tulipanowej i Pomarańczowej rewolucji. Wyklęty lud ziemi walczący o emancypację i samostanowienie wydaje się nie występować na Wschodzie. Wielu mieszkańców Globalnego Wschodu to biali, którzy występują zarówno w roli sprawców, jak i ofiar rasizmu, vide polscy imigranci w Wielkiej Brytanii (Nowicka 2017). „Rosjanie i mieszkańcy Europy Wschodniej stali się po 1989 roku czarnymi w kolorze złamanej bieli nowego globalnego świata - wyglądają i zachowują się aż nazbyt podobnie do naszych, ale ostatecznie są inni” (Tlostanova 2017, 8). Jak podkreślała w przenikli-

Jako taki Wschód

zajmuje niewygodną pozycję pomiędzy w większości postkolonialnymi społeczeństwami Południa i centrami władzy na Północy. To z kolei sprawia, że relacja kolonizator/kolonizowany staje się w przypadku Wschodu wielopoziomowa, gdzie trudno jednoznacznie wskazać metropolię. 
wych słowach Katherine Verdery $(2002,20)$, nie jest jasne, kto miałby zostać Frantzem Fanonem postsocjalistycznego Wschodu. To trudne pytanie, na które odpowiedziałbym: Nie może być Frantza Fanona Wschodu. Ostatecznie do kogo miałby/miałaby mówić i jakim prawem?

Wschód jest więc podrzędny, ale nie w pełni podrzędny. Jest pewnego rodzaju podporządkowanym innym, ale nie do końca. Nie jest zamożny, ale nie jest też biedny. Zawiera w sobie pewne elementy europejskiej nowoczesności, ale brakuje mu innych: zbyt odmienny, by móc go zaliczyć do Północy, zbyt europejski, by włączyć go do Południa. Większość społeczeństw Europy Wschodniej i byłych państw Związku Radzieckiego jest uwikłana w tę pośrednią relację bycia nie do końca Północą i Południem. Mogą być mieszkańcami państw członkowskich Unii Europejskiej, a nawet krajów wysokodochodowych i mimo to nie być pełnoprawnymi członkami klubu. Pomyślcie choćby o Polsce. Albo odwrotnie, mogą być biednymi, byłymi koloniami, takimi jak Tadżykistan czy rosyjski Kaukaz, a i tak nie zaliczać się do Południa. W najlepszym wypadku są „drugorzędnym Południem” (Tlostanova 2011). Próby wypracowania dialogu pomiędzy Południem Globalnego Wschodu, na przykład koloniami Rosji Radzieckiej, a Globalnym Południem zdarzają się bardzo rzadko (Chari i Verdery 2009; Karkov 2015; Tlostanova 2011, 2015b).

To ta liminalność sprawia, że debaty o Globalnej Północy i Południu pomijają Wschód: nie wynika to ze złośliwości, ale z tego, że Wschód nie pasuje do ramy, za pomocą której ujmujemy to, co globalne. To bycie pomiędzy nie zamienia Wschodu w coś pokroju żyznej trzeciej przestrzeni Homiego Bhabhy (2010), strefy wymiany między kulturami i znaczeniami. Wręcz przeciwnie, Wschód wydaje się tkwić w zastoju, gdy reszta świata poszła naprzód, by spowić się siecią globalnych połączeń i mobilności. Jak pisze Mikanowski (2017):

Nieraz zapadłem się w zakamarki Europy Wschodniej, daleko na zachód od granicy wyznaczonej przez Odrę i Triest. Zdarzyło mi się to pod wiaduktami autostrady, w kolejce do okienka DMV [Departament ds. pojazdów mechanicznych w Stanach Zjednoczonych] czy w poczekalni zapomnianej stacji autobusowej. Zawsze wydawało mi się, że Proustowskie momenty są całkowicie fałszywymi konstruktami, literackim urojeniem, ale niech mnie, jeśli nie uderzył mnie zapach zastałego kurzu w łazience w piwnicy jednego z laboratoriów fizyki w Berkeley i natychmiast nie przeniósł na klatkę schodową mieszkania mojej babci w Warszawie, z unoszącym się tam zapachem zatęchłego moczu, niewycieranego kurzu i starej wody po mopie nieosłodzonej żadnym detergentem. 
Mikanowski ujmuje tutaj wschodniość jako poczucie zapomnienia i odcięcia od świata. Wiadukty autostrad, poczekalnie zapomnianych stacji autobusowych, piwnice - globalność wydarza się wszędzie. Wschodniość jest kondycją bezwładu, czymś na kształt wyjęcia poza nawias czasu i przestrzeni.

Ta kondycja zatrzymania się w czasie manifestuje się w sposobie, w jaki odnosimy się do geograficznego obszaru dzisiejszego Wschodu, zawsze wskazując na przeszłość - postsocjalistyczną, poradziecką, dawnego Związku Radzieckiego, Bloku Wschodniego czy Drugiego Świata - tak jakby po niemal 30 latach komunistyczny Wschód wciąż nie odnalazł drogi prowadzącej do teraźniejszości. Takie bestsellery jak Czasy secondhand: Koniec czerwonego człowieka, za którą Swiatłana Aleksijewicz otrzymała literacką Nagrodę Nobla czy Poślij chociaż słowo Orlando Figesa przywołują doświadczenie radzieckie. Najlepiej sprzedające się książki poświęcone bieżącym wydarzeniom dotyczą z kolei nowej domniemanej zimnej wojny. Jedno z najważniejszych czasopism naukowych poświęconych Wschodowi opisuje siebie następująco: „skupia się na historii i bieżących wydarzeniach politycznych, społecznych i ekonomicznych w krajach byłego "bloku komunistycznego"” (Europe Asia Studies 2018).

Wschód jako nienależący, ani do Północy, ani do Południa, ogarnięty bezwładem, zniknął w ogóle z tego, co „globalne”. Spróbujecie wykazać znaczącą rolę Wschodu w debatach dotyczących, powiedzmy, globalnego urbanizmu, handlu globalnego czy globalnej mobilności. Nie chodzi nawet o to, że Wschód jest w nich rzadko przywoływany, co jest oczywiście prawdą. Chodzi raczej o to, że nie jest on ujmowany jako część globalnych połączeń (Rogers 2010). Nie uczestniczy w tym, co „globalne” - globalnych przepływach obrazów i idei, ludzi i polityk. Jeśli „Wschód” istnieje, to nie zasługuje na miano „globalnego”. Trudno byłoby w tym kontekście obwiniać kogoś za przekonanie, że żelazna kurtyna nigdy nie upadła.

\section{Poza zachodnią architekturę wiedzy}

Żelazna kurtyna jednak upadła. Stanowcze przywrócenie Wschodu na mapie powinno nastąpić o wiele wcześniej, szczególnie po to, by zachwiać binarną opozycją Północy i Południa. Odzyskiwanie głosu Wschodu w debatach akademickich może przeciwstawiać się albo chociaż kwestionować dominujące kulturowe obiegi produkcji wiedzy (Buchowski 
2004; Timár 2004)5 i odpowiadające im próby samowykluczenia Wschodu (Funk 2017). Może spróbować przetasować „geopolitykę wiedzy” zorganizowaną wokół dwóch półkuli (Mignolo 2002), które w coraz większym stopniu oznaczają Północ i Południe.

Część politycznego impulsu odzyskiwania Wschodu polega na przywracaniu jego ogromnej różnorodności, która często jest pomijana i redukowana do swojej karykatury w postaci monotonnego „szarego miejsca”. To różnorodność nie tylko etniczna (chociaż i ta istnieje), ale również polityczna, kulturowa czy gospodarcza, która przeczy homogenizującemu przydomkowi „byłego Bloku Wschodniego”, co po dziś dzień pozostaje ulubionym określeniem komentatorów politycznych. Od Estonii jako wizytówki europejskich reform, przez dyktaturę na Białorusi, po globalne ambicje Kazachstanu. Od imperialnego rdzenia, którym niegdyś była Rosja, przez rozdartą konfliktem Ukrainę, po odśrodkowe peryferie słoweńskie. Tę różnorodność i jej wpływ na ludzkie życia być może najlepiej oddaje żart o starszym mężczyźnie, który opowiada, że urodził się w Cesarstwie Austro-Węgierskim, poszedł do szkoły w Czechosłowacji, ożenił się na Węgrzech, pracował przez większość życia w Związku Radzieckim, a na emeryturę przeszedł na Ukrainie. „Zatem dużo podróżowałeś?” - zapytał jego rozmówca. „Nie, nigdy nie wyjechałem z Mukaczewa”.

Co istotniejsze, Wschód nie daje się łatwo dopasować do istniejącej architektury wiedzy w świecie w znacznej mierze anglojęzycznym (Tlostanova 2015a). Język angielski nie dociera tak daleko jako lingua franca, zachodni kolonializm nie stworzył wspólnych instytucji czy więzów rodzinnych, a wpływ istnienia żelaznej kurtyny, która utrudniła zawiązywanie się współpracy badawczej, jest wciąż odczuwalny. Intelektualiści i badacze, którzy wyemigrowali z Globalnego Południa - Stuart Hall, Gayatri Spivak, Edward Said, Achille Mbembe, Aimé Césaire - często trafiali ostatecznie do kolonialnych metropolii w Wielkiej Brytanii, Francji czy Stanach Zjednoczonych, tym samym włączając się w anglojęzyczne i francuskojęzyczne obiegi produkcji wiedzy. Jeśli jednak badacze ze Wschodu, jak to często miało miejsce, wyjeżdżali do Moskwy, do centrum Imperium Radzieckiego, docierali do ograniczonej widowni, a po upadku Związku Radzieckiego mierzyli się z rosnącą izolacją językową i malejącym globalnym zasięgiem. Aspirujący intelektualiści ze

5 Perspektywa postsocjalistycza, jako próba zrozumienia Wschodu po upadku bloku socjalistycznego (por. Hann 2001), była wytworem tych obiegów osadzonych w nauce anglosaskiej. Wschodni naukowcy krytykowali ją jako „orientalizującą koncepcję, za pomocą której zachodni antropolodzy zrekonstruowali postkomunistyczną Europę" (Červinková 2012, 159). 
Wschodu jako język obcy wybierali francuski i niemiecki, a nie angielski jako język rynkowego kapitalizmu. To z kolei wpłynęło na to, w jakich obiegach mogła funkcjonować wiedza ze Wschodu i wiedza o samym Wschodzie. Jak na ironię pozostanie poza wpływami brytyjskiego i francuskiego kolonializmu ograniczyło słyszalność Wschodu.

Kolejnym czynnikiem wpływającym na nieobecność głosów ze Wschodu w globalnej debacie jest cios, jaki wschodniej nauce zadał upadek socjalizmu. Jego skutki są odczuwalne po dziś dzień. Nie tylko z dnia na dzień zniknęło finansowanie, ale też sami naukowcy znaleźli się w sytuacji, w której kryteria bycia dobrym naukowcem radykalnie się zmieniły. Wielu z nich odeszło z akademii i opuściło swój kraj w poszukiwaniu szansy na przeżycie. Natomiast ci, którzy zostali, musieli (i wciąż czasem musza) dorabiać na boku, zwłaszcza w takich obszarach jak humanistyka czy nauki społeczne, którym odmawiano większej wartości praktycznej. Praca akademicka nie oferowała żadnych perspektyw i godnych zarobków, więc niewielu młodych naukowców mogło pozostać w akademii w latach dziewięćdziesiątych i dwutysięcznych, a tym samym wnieść realny wkład w toczące się debaty. Zamiast tego wyjeżdżali studiować i pracować zagranicą (Ushkalov i Malakha 2010). W tym kontekście nie dziwi, „że zniesienie ograniczeń publikowania i same społeczne transformacje w Europie Środkowej i Wschodniej nie doprowadziły do wysypu nowych krajowych analiz rzeczywistości komunistycznej i postkomunistycznej” (Outhwaite i Ray 2005, 12). Jak to możliwe? Upadek socjalizmu niemalże zrujnował badania na Wschodzie, a sytuacja dopiero niedawno zaczęła się powoli zmieniać.

\section{W stronę strategicznego esencjalizmu Wschodu}

Biorąc pod uwagę te uwarunkowania, polityczny projekt odzyskania głosu przez Wschód staje się jeszcze istotniejszy. Uważam, że podejmując się tego zadania, powinniśmy pozostać przy pojęciu „Wschodu” i nie wzbraniać się od konfrontacji z jego dawnymi konotacjami zacofania i inności. Dlatego też takie pojęcia jak „Nowa Europa” czy „Europa Środkowa” (Garton Ash 1999; Kundera 1984), które usiłują się odciąć od Wschodu, ryzykują reprodukowanie teleologicznego horyzontu Europy i popadnięcie w europocentryzm. Jak zauważyli różni badacze (Kuus 2004; Melegh 2006), takie zabiegi wyłącznie przesuwają granice „zacofanego Wschodu” bardziej na Wschód, umiejscawiając Innego gdzie indziej, zamiast całościowo z nim zerwać. Równie istotne jest myślenie o Wschodzie - podobnie jak o Północy i Południu - przede
Aspirujący intelektualiści ze Wschodu jako język obcy wybierali francuski i niemiecki, a nie angielski jako język rynkowego kapitalizmu. To z kolei wpłynęło na to, w jakich obiegach mogła funkcjonować wiedza ze Wschodu i wiedza o samym Wschodzie. 
wszystkim nie w kategoriach geograficznych, ale ontologicznych i epistemologicznych. Dzięki temu można uniknąć ryzyka ograniczania go do odgraniczonego regionu świata.

Wschód to rzecz jasna polisemiczne i plastyczne pojęcie. W jego różnych użyciach rozciąga się od Europy Wschodniej po Rosję, Japonię i Chiny, aż do tego, co niekiedy nazywane jest Bliskim Wschodem, łącznie z Turcją (Goody 1996; Mahbubani 2008; Mignolo 2014b; Neumann 1999; Said 2005; Zarakol 2011). Jedną z jego trwałych cech jest służenie za innego afirmowanemu w ten sposób Zachodowi. Niniejszy artykuł rozwija prezentowany argument, myśląc przez pryzmat jednego z tych wielu Wschodów: tych społeczeństw byłego Drugiego Świata, które doświadczyły efektu domino w postaci upadku socjalizmu w latach 1989-1992. Jeśli jednak wschodniość jest kłopotliwym położeniem połowicznej inności, pojęcie Globalnego Wschodu nie powinno ograniczać się do tych społeczeństw. W rzeczywistości powinno odnosić się do wszystkich tych, którzy nie znajdują się ani tu, ani tam.

Ta jego plastyczność jest niezwykle przydatna w przypadku pojęć takich jak Globalny Wschód, ponieważ sugeruje nie tyle ostre granice i dookreślone terytoria, a związki topologiczne i nieostre obszary. Wschód jest zawsze gdzie indziej: gdy pytam o niego we Francji, słyszę, że Wschód jest w Niemczech, sami Niemcy wskazują Niemcy Wschodnie, z kolei mieszkańcy wschodnich landów przesuwają granicę Wschodu w stronę Polski, Polacy zaś lokują Wschód na Ukrainie... ciągłe przemieszczenie znaczonego związanego ze znaczącym - Wschodem. „Wschód” można zatem określić jako płynne znaczące, znaczące pozbawione określonego znaczonego. Znaczące mówi nam więcej o osobie, która się nim posłużyła niż o denotowanym przedmiocie. Cecha ta sprawia, że jest odpowiedni dla politycznego projektu ponownego użycia pojęcia Wschodu. Jak twierdził Laclau (2009), płynne znaczące umożliwiają artykulację żądań politycznych, ponieważ są zdolne do ujęcia wielości znaczeń (w terminologii samego Laclau łączą one polityczne żądania w łańcuchu ekwiwalencji). Dzięki temu, że same nie mają żadnego określonego znaczenia, mogą posłużyć do nadpisania na nich różnych znaczeń.

To ta cecha plastyczności, otwartości i wskazywania poza określone terytoria jest znacznie mniej obecna w takich pojęciach jak „Euroazja”, które stało się popularnym określeniem znacznych części dawnego Związku Radzieckiego (w szczególności Rosji i Azji Centralnej) (Grant 2012; Hann et al. 2016). Euroazja jest zdecydowanie terytorialnym pojęciem, które ponadto posiada problematyczne znaczenie związane z ideologią eurazjatycką, która w ostatnim czasie odrodziła się w Rosji 
(Suslov i Bassin 2016). Ideologia ta dostarczyła nacjonalistom i siłom ekstremistycznym w Rosji moralnej i pseudonaukowej legitymizacji dla ich dążeń do ideologii imperialnej. Laruelle $(2016,136)$ podsumowuje ten problematyczny aspekt następująco: „[Eurazja] wyraża, w wygodny i raczej intuicyjny sposób, historyczne terytorium Rosji i jej "peryferii«, jak również pewną przyspieszającą rzeczywistość geopolityczną (...). W krajach takich jak Państwa Bałtyckie czy Ukraina bycie poddawanym badaniom akademickim w ramach wydziałów Eurazji budzi obawy". Z kolei Smith i Richardson (2017, 4-5) nazywają Eurazję „mitem”: „niespójnym mętlikiem przestrzeni (...). Eurazję można dostrzec w całym wachlarzu postaci (...) definiowanym przez niejednolitość i niespójność”.

Jeśli przyjmiemy założenie polifonii i niespójności, być może najlepiej będzie pomyśleć nam o Wschodzie jako formie strategicznego esencjalizmu (Spivak 2010): politycznej praktyce mobilizowania heterogenicznych i zmarginalizowanych grup do zjednoczenia się pod jednym sztandarem w celu realizacji politycznego projektu emancypacyjnego. Strategiczny esencjalizm zakłada tymczasowe odłożenie różnic w celu artykulacji żądań politycznych względem hegemonicznego dyskursu. W tym kontekście wiele kwestii może mieć charakter „polityczny”: prawo do uznania, produkcja tego, co zostanie uznane za przyjętą wiedzę, wolność od dyskryminacji. Tego rodzaju strategiczny esencjalizm był istotną taktyką służącą artykulacji żądań w feminizmie (Rose 1993), postkolonializmie (Spivak 1993), a ostatnio na rzecz Globalnego Południa (Comaroff i Comaroff 2011; Parnell i Robinson 2012).

Przypadek Globalnego Południa, który też należy traktować jako przykład strategicznego esencjalizmu, jest w tym kontekście szczególnie pouczający, gdyż również dotyczy zmarginalizowanej oraz wysoce heterogenicznej kategorii i odzyskania paternalistycznego pojęcia. W rzeczywistości, gdy pojęcie „Południa” (pozbawione wówczas jeszcze przymiotnika "globalne”) pojawiło się w dyskusjach z lat siedemdziesiątych, było niczym więcej niż słabo zamaskowanym zamiennikiem „krajów rozwijających się”, który odsyłał do paternalistycznej odpowiedzialności Północy za skorygowanie nierówności i „ocalenie” biednego Południa. Było bardziej wsteczne niż pojęcie „Trzeciego Świata”, które stało się własnym politycznym projektem Południa, począwszy od Konferencji w Bandungu w 1995 roku (Dirlik 2007; Prashad 2013).

Współczesne dążenie do podjęcia teoretycznego myślenia z perspektywy Południa i unieważnienia telosu nowoczesności (związanego z Globalną Północa) na nowo ustanowiło znaczenie Południa (Chakrabarty 2011; Comaroff i Comaroff 2011; Robinson 2006): Południe nie tylko może i musi samo w sobie stanowić źródło teoretycznego myślenia, ale 
te teoretyczne spostrzeżenia muszą też docierać do myślenia teoretycznego na Północy ${ }^{6}$.

Ten argument jest być może najmocniej wyrażony w stanowisku Comaroffów (2011), którzy postrzegają Północ, z jej nieustannymi kryzysami, brakiem stabilności i bezpieczeństwa, polityką zaciskania pasa i społecznymi oraz etnicznymi podziałami, jako ewoluującą w kierunku Południa. Tym samym to Południe jest, ich zdaniem, siłą napędową teoretycznego myślenia o tej nowej kondycji. „Tak zwana "Nowa Normalność Północy jest odtwarzaniem niedawnej przeszłości Wschodu”

Wysiłek Południa

na rzecz emancypacji

może stanowić dla

Wschodu wzór w jego własnych politycznych wysiłkach dekolonizacji

produkcji wiedzy

i ponownego umieszczeniu na mapie. Proces

ten nie może jednak

zajść bez myślenia o Wschodzie w kontekście globalnym: jako Globalnym Wschodzie. (Comaroff i Comaroff 2012, 123) 7 . Północ jako doganiająca Południe: cóż za ożywczy sposób postawienia świata na głowie. Chociaż ich argument opiera się przede wszystkim na zgubności globalnych rządów neoliberalizmu - które wydają się coraz bardziej chwiejne w związku ostatnimi tendencjami nacjonalistycznymi - jego ciężar jest jasny: Południe ma coś do powiedzenia nie tylko sobie, ale również Północy.

Wysiłek Południa na rzecz emancypacji może stanowić dla Wschodu wzór w jego własnych politycznych wysiłkach dekolonizacji produkcji wiedzy i ponownego umieszczeniu na mapie. Proces ten nie może jednak zajść bez myślenia o Wschodzie w kontekście globalnym: jako Globalnym Wschodzie.

\section{Globalny Wschód: na tropie szklanki z fazowanego szkła}

Spróbujmy teraz pomyśleć o Globalnym Wschodzie, który nie jest odcięty od świata jako byt zastygły w czasie i przestrzeni. Spójrzmy na Globalny Wschód przez pryzmat szklanki z fazowanego szkła (Rysunek 1), a zatem klasycznego produktu IKEI. Szklankę z fazowanego szkła można znaleźć na całym świecie. Pojawia się na stołach zarówno prezydentów, jak i studentów. Stoi zaraz obok mnie, na moim biurku. Założę się, że miały ją w swoich rękach także czytelniczki tego tekstu. Nie ma oficjalnych danych, ale w oparciu o moje codzienne obserwacje szafek różnych ludzi w wielu zakątkach świata sądzę, że sprzedaż tych szklanek liczy się w miliardach. Nie dziwi zatem, że kosztując niecałe 70 centów

6 To prawda także w przypadku niedawnej tendencji do tworzenia azjatyckich teorii w „stuleciu Azji”; zob. np. Asia as Method (2010) Kuan-Hsing Chen i The New Asian Hemisphere (2008) Kishore Mahbubani.

7 Częste powoływanie się na różnice między Północą a Południem nie powinny przysłaniać tego, że literatura zaczęła przyglądać się stosunkom, które przecinają Północ i Południe, rozmywając granice (por. Caison i Vormann 2015; Roy i Crane 2015). 
za sztukę, szklanka z fazowanego szkła jest konkurencyjnym produktem i opiera się niemalże wszystkim próbom, zamierzonym czy nie, jej detronizacji. Choć większość z nas uważa ją za wytwór IKEI, fazowanie to materializacja Wschodu, która upowszechniła się globalnie. Projekt IKEI nie kryje swoich inspiracji klasycznym radzieckim projektem granionyj stakan (гранёный стакан) - klasyki radzieckiej zastawy przynajmniej od 1943 roku - autorstwa Wiery Muchiny (Idov 2011, 78).
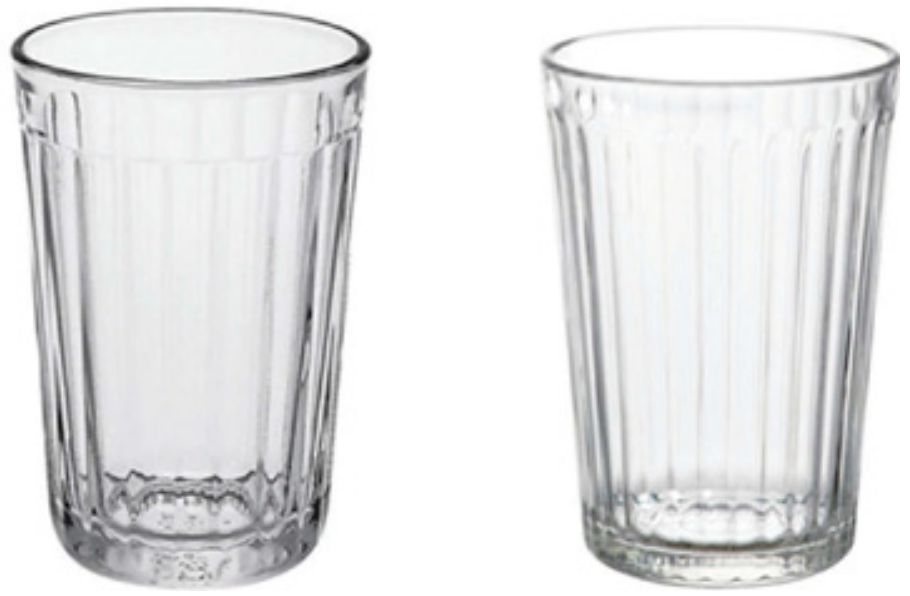

Rysunek 1 - Znajdź różnice: Sowiecki granionyj stakan (po lewej) i współczesna reinterpretacja IKEI pod nazwą Vardagen (po prawej)

Można by ulec pokusie pomyślenia o szklance z fazowanego szkła jako kolejnej opowieści o „banalnym kosmopolityzmie kultury konsumenckiej" (Featherstone 2006, 390) i czerpaniu inspiracji z (a może kradzieży?) lokalnej wiedzy przez globalne korporacje. Ale to coś znacznie więcej. Po pierwsze, granionyj stakan osiągnął wcześniej ogromny sukces na Wschodzie, gdzie po drugiej wojnie światowej produkowano 5 do 6 milionów szklanek rocznie (Idov 2011, 80). Trzeba ją zatem odczytywać raczej jako globalny produkt konsumencki zaprojektowany na Wschodzie i skopiowany na Zachodzie. Tym samym jest to rzadko spotykane odwrócenie zwyczajowego porządku rzeczy w świecie, w którym projektowanie staje się przywilejem kreatywnych centrów Globalnej Północy, co unaocznia sformułowanie „zaprojektowane w Kalifornii, wyprodukowane w Chinach", wszechobecne na produktach Apple.

Jednak za szklanką z fazowanego szkła stoi też cała historia produkcji. Większość ikeowskiej zastawy produkuje się na Globalnym Wschodzie. Za konkurencyjnością przemawiają tu tanie nakłady (przede wszystkim energia) i rozwinięty przemysł szklany. IKEA produkowała przez 
długi czas swój najpopularniejszy element zastawy, czyli Pokal (zob. Rysunek 2), w Rosji, by następnie przenieść się do Bułgarii, prawdopodobnie ze względu na to, że łączy ona utrzymujące się na niskim poziomie koszty produkcji z członkostwem w UE, co ułatwiło eksport.

Losy szklanki z fazowanego szkła to historia pośredniej pozycji Globalnego Wschodu pod kątem zarówno jej wkładu w globalizację, jak i bycia jej beneficjentem. „Zaprojektowane na Globalnym Wschodzie, wyprodukowane na Globalnym Wschodzie" - oto formuła, która wyraża dualizm Globalnego Wschodu w kontekście globalizacji. Stanowi jednocześnie ilustrację dla kolejnego istotnego twierdzenia: Wschód jest uwikłany w stosunki globalne. Nie jest odosobniony, ale tworzy więzi ze światem. Taki wniosek zdaje się oczywisty, ale Wschód, jak widzieliśmy wyżej, często postrzega się jako coś zupełnie przeciwnego: jako wyjęty poza margines czasu i przestrzeni.
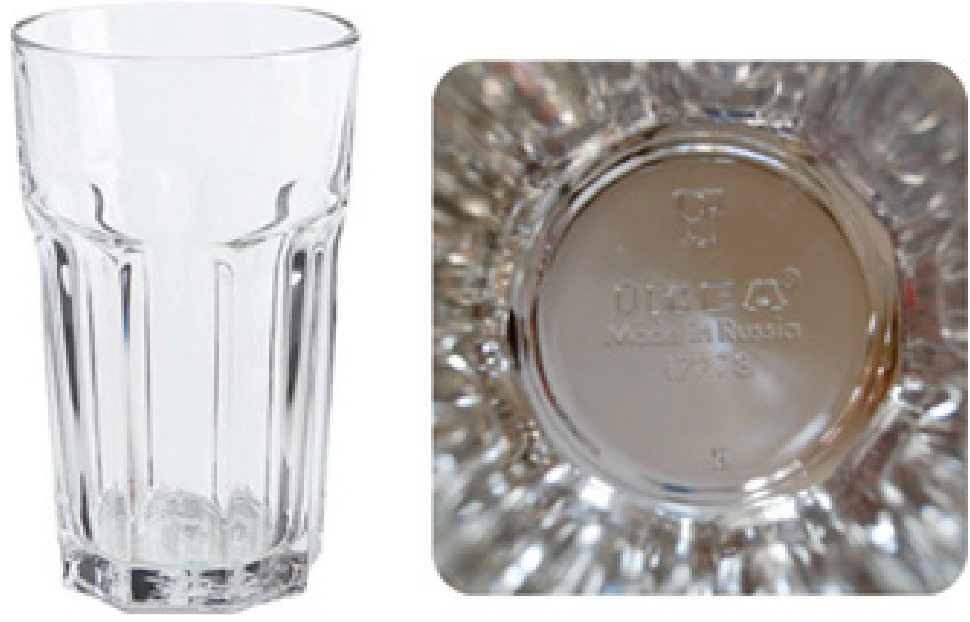

Rysunek 2 - Wytworzone na Globalnym Wschodzie: flagowa szklanka IKEI Pokal

Postrzeganie Globalnego Wschodu w kategoriach relacyjnych zakłada topologiczne pojmowanie Wschodu (Shields 2012; co do Wschodu w szczególności, zob. Rogers 2010; Tuvikene 2016), gdzie każde miejsce może stać się jego częścią dopóty, dopóki jest zaangażowane w odpowiednie relacje. Materialna obecność ikeowskiej szklanki na moim biurku, tuż przede mną, łączy mnie z Globalnym Wschodem, podobnie jak wydanie Made in Russia leżące zaraz obok. Innymi słowy, wyzwaniem, jakie rzuca nam Globalny Wschód, jest myślenie w kategoriach topologicznych: tropienie stosunków, które przybliżają to, co dalekie 
i wiążą ze sobą nieprzylegające byty (Mol i Law 1994). Jako relacja Globalny Wschód może być wszędzie. Pytanie „gdzie jest Globalny Wschód?” jest zatem nietrafione, ponieważ odsyła nas do terytoriów. Lepiej zapytać „czym jest Globalny Wschód”, co zaprowadzi nas ku relacjom.

Celem relacyjnego ujęcia Wschodu jest zaiste uniknięcie ograniczania się do obszarów dawnego Drugiego Świata. Gdy radziecki pisarz Ilja Erenburg stwierdził, że Berlin jest macochą rosyjskich miast, wskazywał na translokalną relację Wschodu. Erenburg był jednym z setek tysięcy uchodźców udających się na migrację w następstwie Rewolucji Październikowej. Znalazł ersatz domu w Berlinie, który uczynił, by zacytować Karla Schlögela, zastępczą stolicą (Ersatzhauptstadt; Schlögel 2007). Nie trzeba jednak cofać się w czasie do Charlottengradu sprzed stu lat, by przekonać się, że Globalny Wschód jest wszędzie: w rosyjskojęzycznych społecznościach Małej Odessy w Nowym Jorku (Miyares 1998) i Limmasolu na Cyprze, w zbiorowościach wschodnioeuropejskich w Londynie (Neumann 2015), pośród transnarodowych ewangelików w Ukrainie (Wanner 2007). Jest obecna także w rosyjskich interwencjach w wybory w Stanach Zjednoczonych, w „wędrownych matkach” podróżujących między Mołdawią a Stambułem (Keough 2016), w powiązaniach między reżimami naftowymi w Azji Centralnej a Zatoką Perską (Koch 2016), w promocji Gruzji na skalę światowej jako wizytówki reformy postsowieckiej (Schueth 2011) - a także w historii produktów konsumenckich takich jak granionyj stakan.

W pewien sposób najciekawszym aspektem Wschodu nie jest jego rdzeń, ale jego przedłużenia i obszary wymiany. Podążanie za tymi przedłużeniami otwiera przed nami nowe możliwości porównywania krajów, zjawisk i miejsc, które na pierwszy rzut oka wydają się zbyt różne dla budowania analogii, ale właśnie z tego względu ich porównanie może nas doprowadzić do owocnych wniosków. Zestawienie ze sobą neopatrymonialnych państw wojskowych takich jak Stany Zjednoczone i Rosja, nowoczesności skonstruowanych w Taszkiencie i Brazylii, a także ewangelików z Ukrainy i Nigerii ma ważką funkcję poznawczą: zapobiega postrzeganiu Wschodu w kategoriach radykalnej odmienności i jego egzotyzacji jako Innego. Decentralizuje też Zachód i roszczenia do uniwersalności wywodzącej się stamtąd wiedzy (Robinson 2016; Sidaway 2013) .

8 Bieżąca literatura dotycząca Globalnych Północy i Południa podkreśla te topologiczne powiązania Południa z Północą (np. w kwestii grodzonych osiedli) i Północy z Południem (np. w aspekcie biedy) (por. Miraftab 2009; Roy i Crane 2015).

W pewien sposób najciekawszym aspektem Wschodu nie jest jego rdzeń, ale jego przedłużenia i obszary wymiany. Podążanie za tymi przedłużeniami otwiera przed nami nowe możliwości porównywania krajów, zjawisk i miejsc, które na pierwszy rzut oka wydają się zbyt różne dla budowania analogii, ale właśnie z tego względu ich porównanie może nas doprowadzić do owocnych wniosków. 
Badanie powiązań odkrywa powinowactwo koncepcji Globalnego Wschodu z trzecią falą badań regionalnych, ukształtowanych w dużej mierze przez proces globalizacji, połączenia i mobilność oraz inspiracje teorią społeczną i kulturową (Middell 2013; Mielke i Hornidge 2016; Sidaway et al. 2016). Ta trzecia fala, w związku ze swoją autorefleksyjnością, krytycznie podchodzi do uprzednich założeń odnośnie regionów jako ograniczonych i do kolonialnej produkcji wiedzy o regionach z pozycji centrum, zamiast tego proponując analizę globalnych powiązań i decentralizację produkcji wiedzy. Dlatego też szukają niestabilnego punktu środka między całościowym odrzucaniem zlokalizowanej wiedzy na rzecz niezakorzenionych studiów globalnych (Koch 2016, 650) a urzeczowieniem regionów jako zamkniętych bytów (van Schendel 2002). W kontekście Globalnego Wschodu warto pamiętać o tym, że wiedza miejscowa jest ważna, ale niekoniecznie musi być przypisana poszczególnym regionom jako rama epistemologiczna. Innymi słowy, miejsce genezy wciąż jest istotne, ale nie decyduje o wszystkim. Miejsca mogą generować afordancję, szczególną możliwość działania, która może, ale nie musi się urzeczywistnić. Jak ujął to Chari (2016, 792), musimy zobowiązać się do „bycia-z w świecie współwystępujących powiązań i różnicy ontologicznej”. Trzeba zatem zaczać budować Globalny Wschód przez globalne poczucie przynależności: nie jako zamknięty w sobie i wycofany, ale zwrócony na zewnątrz przy zachowaniu wszystkiego, co konstytuuje jego swoistość (Massey 1991).

\section{Zakończenie: Tworząc teorię razem z Globalnym Wschodem}

Myśląc o świecie jako podzielonym na Globalną Północ i Globalne Południe, Wschód został zepchnięty w swoisty niebyt. Pośredniość jego pozycji - nie do końca zamożny, ale również nie do końca biedny; nie tylko kolonia i nie tylko kolonizator - sprawiła, że trudno go skategoryzować. Został obsadzony w roli zacofanego i odizolowanego. Nauka i dyskurs publiczny mają skłonność do ujmowania Wschodu jako w pewien sposób oddzielonego i oddalonego od świata, jako bytu, który nie ma mu nic szczególnego do zaoferowania.

Niniejszy artykuł argumentował na rzecz ujęcia Wschodu jako Globalnego Wschodu w celu odzyskania jego miejsca i głosu w świecie. Oznacza to myślenie o Wschodzie jako formie strategicznego esencjalizmu, co pozwala na ponowne ustanowienie go adekwatnym przedmiotem zainteresowania nauki i nadpisaniu na nim nowych znaczeń. Traktowanie Wschodu jako Globalnego Wschodu oznacza umieszczenie go 
w samym środku świata. Jeśli postrzegamy Globalny Wschód jako uwikłany w wielość innych miejsc, pozostawienie go na marginesie myślenia teoretycznego staje się trudniejsze. Nie będąc ani Północą, ani Południem, pozwala nam uniknąć opozycji binarnych zorganizowanych wokół dwóch półkuli w myśleniu o tym, co globalne: zamożne i biedne, potężne i słabe. Zaangażowanie się w globalne badania porównawcze przeciwdziała izolacji Wschodu, pozwalając wyrazić wielość jego doświadczeń - imperium, globalizacji, reform neoliberalnych, nacjonalistycznego populizmu, oporu politycznego i niesymetrycznych konfliktów - w ramach podobnych debat odbywających się w innych miejscach.

Myślenie o Globalnym Wschodzie jest zatem również projektem politycznym. Nie tylko przeciwstawia się połowicznemu wyobcowywaniu Wschodu na Północy i milczeniu o Wschodzie na Południu, usiłując w ten sposób nadać wartość doświadczeniom ludzi ze Wschodu i wyrugować eurocentryzm, ale afirmuje również Wschód jako otwarte miejsce, wychodzące naprzeciw, a nie wycofujące się. Wraz z dostrzegalną falą nacjonalistycznego populizmu na Północy, Południu i Wschodzie, która usiłuje raczej odgrodzić od siebie państwa, zamiast budować między nimi mosty, ta widoczna otwartość staje się istotnym oświadczeniem politycznym. Wraz z niepokojami w rzekomych ośrodkach demokracji liberalnej, czyli w Wielkiej Brytanii i Stanach Zjednoczonych, ten polityczny projekt pojawia się być może w odpowiednim czasie, gdy różnice między Północą a Południem, Wschodem i Zachodem stają się coraz mniej wyraźne, a ustanowione między nimi hierarchie są podawane w wątpliwość.

Chociaż niniejszy artykuł konceptualizował Globalny Wschód z perspektywy dawnych społeczeństw socjalistycznych Drugiego Świata, kondycja wschodniości - pół-inności, która waha się między Północą a Południem - rozciąga się znacznie dalej. Co z Koreą Południową, Turcją czy złowieszczym Bliskim Wschodem? Myślenie razem ze Wschodem oznacza kres przemilczeń zrodzonych przez dwubiegunowy podział Północ-Południe i wychodzenie nie tyle od jego marginesów, ale raczej jego pośredniości. Nie chodzi tutaj również o przywrócenie innej opozycji binarnej - Wschód-Zachód - ale zdestabilizowanie binarnej wyobraźni geopolitycznej za pomocą wprowadzenia tertium quid.

Przyjmując Globalny Wschód za tertium quid, powinniśmy jednocześnie przyjąć jego liminalną pozycję, jego połowiczną inność. Klasyczna odpowiedź na ten problem zakładała myślenie o pośredniości jego pozycji jako czymś wymagającym usunięcia, co wymaga przejścia do innego stanu, od peryferii do centrum. Czemu jednak nie myślimy o tej liminalności jako zalecie? Czemu nie wykorzystujemy zasobów, których 
dostarcza ona w mierzeniu się z niepewnościami, nieprzewidywalnościami i improwizowanymi taktykami? Myślenie z pozycji pomiędzy Północą i Południem oznaczałoby zatem myślenie o dwuznaczności i efemeryczności - nie tylko w kontekście Wschodu, ale też Północy i Południa.

W ten sposób zaakceptowanie jego liminalności wpisuje Globalny

Czemu jednak nie myślimy o tej liminalności jako zalecie? Czemu nie wykorzystujemy zasobów, których dostarcza ona w mierzeniu się z niepewnościami, nieprzewidywalnościami i improwizowanymi taktykami?

Wschód nie tylko w wielość debat toczących się wokół geopolityki wiedzy (Mignolo 2002) - trzeciej fali badań regionalnych, które podejmują kwestię polityki reprezentacji i wysuwają na pierwszy plan transnarodowe połączenia (Sidaway et al. 2016) oraz konieczność teoretycznego myślenia z wewnątrz Południa (Connell 2018) - ale również wydobywa znaczenie myślenia razem ze Wschodem dla konceptualizacji paradoksów i niepewności charakteryzujących zglobalizowane społeczeństwa, które w ostatnich kilku dekadach cieszyły się znacznym zainteresowaniem wśród naukowców (Bauman 2007; Prigogine 1996; Žižek 2011).

Dlatego teoretyczne myślenie o Globalnym Wschodzie nie wystarczy. Ponowne ustanowienie Globalnego Wschodu nie może się wydarzyć bez zrewolucjonizowania produkcji wiedzy o nim samym. Podejmując się tego zadania, musimy przekształcić Wschód z przedmiotu badań regionalnych w podmiot, a właściwie w metodę - jako „środki przekształcenia produkcji wiedzy” (Chen 2010, 216). To, co doprowadzi do ponownego ustanowienia Wschodu, nie jest bez znaczenia. Dzisiejszy napływ wiedzy z Globalnego Wschodu nie pozostawia żadnych wątpliwości, że nadszedł czas na teoretyczne myślenie nie tylko o nim, ale wspólnie z nim.

\section{Podziękowania}

Ten artykuł to druga część tetralogii publikacyjnej. Pozostałe części to: Goodbye Postsocialism! (Müller 2019), Theorising with the Global East oraz How global is global urbanism? How we theorised from the South but forgot about the East. Niniejsza praca, w różnych jej postaciach, wiele zyskała dzięki licznym, zaangażowanym odbiorcom w Wielkiej Łomnicy we wrześniu 2016 roku, w Lipsku w listopadzie 2016 roku, w Bostonie w kwietniu 2017 roku, w Jekaterynburgu i w Münster (Valais) w sierpniu 2017 roku, Kijowie we wrześniu 2017 i Zürichu w lutym 2018 roku. Dziękuję Elenie Trubinie i Carolin Schurr za przenikliwe uwagi, a także recenzentom i redaktorom z Geopolitics, którzy wpłynęli na ostateczny kształt tego artykułu. 


\section{Wykaz literatury}

Babones, Salvatore, i Philipp Babcicky. 2011. „Russia and Eastern Europe in the modern world-system: A structuralist perspective." Proceedings of the 10th Biennial Conference of the Australasian Association for Communist and Post-Communist Studies, 1-20. https://ses.library. usyd.edu.au/bitstream/2123/8065/2/Russia-and-East-CentralEurope-in-the-modern-world-system.pdf.

Bauman, Zygmunt. 2007. Płynne czasy: Życie w epoce niepewności. Tłum. Maciej Żakowski. Warszawa: Wydawnictwo Sic!

Bhabha, Homi K. 2010. Miejsca kultury. Tłum. Tomasz Dobrogoszcz. Kraków: Wydawnictwo Uniwersytetu Jagiellońskiego.

Boycko, Maxim, Andrei Shleifer, i Robert Vishny. 1995. Privatizing Russia. Cambridge: MIT Press.

Bradbury, Malcom. 1986. Why Come to Slaka? London: Martin Secker \& Warburg.

Bradshaw, Michael. 2001. „The Post-socialist States in the World Economy: Transformation Trajectories." Geopolitics 6(1): 27-46. https:// doi.org/10.1080/14650040108407705.

Braveboy-Wagner, Jacquelline A. 2009. Institutions of the Global South. London: Routledge.

Buchowski, Michał. 2004. „Hierarchies of knowledge in Central-Eastern European Anthropology." Anthropology of East Europe Review 22(2): 5-14.

Caison, Gina, i Boris Vormann. 2015. „The Logics and Logistics of Urban Progress: Contradictions and Conceptual Challenges of the Global North-South Divide." The Global South 8(2): 65-83. https:// doi.org/doi: 10.2979/globalsouth.8.2.65.

Červinková, Hana. 2012. „Postcolonialism, Postsocialism and the Anthropology of East-Central Europe." Journal of Postcolonial Writing 48(2): 155-163. https://doi.org/10.1080/17449855.2012.658246.

Chakrabarty, Dipesh. 2011. Prowincjonalizacja Europy: Myśl postkolonialna i różnica historyczna. Tłum. Dorota Kołodziejczyk, Tomasz Dobrogoszcz i Ewa Domańska. Poznań: Wydawnictwo Poznańskie. Chari, Sharad. 2016. „Trans-area Studies and the Perils of Geographical "world-Writing"." Environment and Planning D: Society and Space 34(5): 791-798. https://doi.org/10.1177/0263775816656522.

Chari, Sharad, i Katherine Verdery. 2009. „Thinking between the Posts: Postcolonialism, Postsocialism, and Ethnography after the Cold War." Comparative Studies in Society and History 51(1): 6-34. https:// doi.org/10.1017/S0010417509000024. 
Chen, Kuan-Hsing. 2010. Asia as Method: Toward Deimperialization. Durham: Duke University Press.

Cilauro, Santa, Tom Gleisner, i Rob Sitch. 2004. Molvanîa: A Land Untouched by Modern Dentistry. Woodstock: The Overlook Press.

Comaroff, Jean, i John L. Comaroff. 2012. „Theory from the South: Or, how Euro-America Is Evolving toward Africa." Anthropological Forum 22(2): 113-131. https://doi.org/10.1080/00664677.2012. 694169.

Comaroff, John L., i Jean Comaroff. 2011. Theory from the South or, How Euro-America Is Evolving toward Africa. Boulder: Paradigm. Connell, Raewyn W. 2018. Teoria z globalnego Południa. Tłum. Paweł Tomanek. Kraków: NOMOS.

Dirlik, Arif. 2007. „Global South: Predicament and Promise.” The Global South 1(1): 12-23. https://doi.org/10.2979/gso.2007.1.1.12.

Europe-Asia Studies. 2018. Europe-Asia Studies. 14 marca. https://www. tandfonline.com/action/journalInformation?show=aimsScope\&jou rnalCode $=$ ceas 20 .

Fanon, Frantz. 1952. Peau noire, masques blancs. Paris: Éditions du Seuil. Fanon, Frantz. 2020. Czarna skóra, białe maski. Tłum. Urszula Kropiwiec. Kraków: Wydawnictwo Karakter.

Featherstone, Mike. 2006. „Genealogies of the Global.” Theory, Culture \& Society 23(2-3): 387-392. https://doi.org/10.1177/0263276406062704.

Fukuyama, Francis. 2009. Koniec historii. Tłum. Tomasz Bieroń i Marek Wichrowski. Kraków: Wydawnictwo Znak.

Funk, D.A. 2017. И Вновь О “качественных Журналах" и Национальных Рейтингах (One More Word about "good Journals" and National Rankings). Sibirskie Istoricheskie Issledovaniya 1 (marzec): 6-11. https://doi.org/10.17223/2312461X/15/1.

Garton Ash, Timothy. 1999. „The Puzzle of Central Europe.” The New York Review of Books, 18 marca. http://www.nybooks.com/articles/1999/03/18/the-puzzle-of-central-europe/.

Gille, Zsuzsa. 2016. Paprika, Foie Gras, and Red Mud: The Politics of Materiality in the European Union. Bloomington: Indiana University Press.

Goody, Jack. 1996. The East in the West. Cambridge: Cambridge University Press.

Grant, Bruce. 2012. „We Are All Eurasian”. Newsnet 52(1): 1-6.

Hann, Chris (red.). 2001. Postsocialism: Ideals, Ideologies and Practices in Eurasia. London: Routledge.

Hann, Chris, M. Benovska-Sabkova, A. Bošković, T. H. Eriksen, D. N. Gellner, A. Gingrich, N. Kradin, J. de Pina-Cabral, G. Lins Ribeiro, 
D. Rogers, G. Schlee, P. Skalník, i D. Wengrow. 2016. „A Concept of Eurasia." Current Anthropology 57(1): 1-27. https://doi. org/10.1086/684625.

Hann, Chris, Caroline Humphrey, i Katherine Verdery. 2002. „Introduction: Postsocialism as a Topic of Anthropological Investigation.” W Postsocialism: Ideals, Ideologies and Practices in Eurasia, red. Chris Hann. Abingdon: Routledge.

Horvat, Srećko, i Igor Štiks. 2012. „Welcome to the Desert of Transition! Post-Socialism, the European Union, and a New Left in the Balkans." Monthly Review (blog), 1 marca. https://monthlyreview. org/2012/03/01/welcome-to-the-desert-of-transition/.

Idov, Michael. 2011. Made in Russia: Unsung Icons of Soviet Design. New York: Rizzoli.

Karkov, Nikolay. 2015. „Decolonizing Praxis in Eastern Europe: Toward a South-to-South Dialogue." Comparative and Continental Philosophy 7(2): 180-200. https://doi.org/10.1179/1757063815Z.00000000061.

Keough, Leyla J. 2016. Worker-mothers on the Margins of Europe: Gender and Migration between Moldova and Istanbul. Bloomington: Indiana University Press.

Knox, Paul, John Agnew, i Linda McCarthy. 2014. The Geography of the World Economy, wyd. 6. Abingdon: Routledge.

Knudsen, Ida H., i Martin D. Frederiksen (red.) 2015. Ethnographies of Grey Zones in Eastern Europe: Relations, Borders and Invisibilities. London: Anthem.

Koch, Natalie. 2016. „Is a »Critical « Area Studies Possible?” Environment and Planning D: Society and Space 34(5): 807-814. https://doi.org/ 10.1177/0263775816656524.

Kovačević, Nataša. 2008. Narrating Post/communism: Colonial Discourse and Europe's Borderline Civilization. London: Routledge.

Kundera, Milan. 1984. „Zachód porwany albo tragedia Europy Środkowej." Zeszyty Literackie 5: 14-31.

Kuus, Merje. 2004. „Europe's Eastern Expansion and the Reinscription of Otherness in East-Central Europe." Progress in Human Geography 28(4): 472-489. https://doi.org/10.1191/0309132504ph498oa.

Kuus, Merje. 2007. „Something Old, Something New: Eastness in European Union Enlargement." Journal of International Relations and Development 10(2): 150-167. https://doi.org/10.1057/palgrave. jird.1800121.

Kuus, Merje. 2014. Geopolitics and Expertise: Knowledge and Authority in European Diplomacy. Oxford: Wiley-Blackwell.

Laclau, Ernesto. 2009. Rozum populistyczny. Tłum. Tomasz Szkudlarek 
et al. Wrocław: Wydawnictwo Naukowe Dolnośląskiej Szkoły Wyższej. Laruelle, Marlene. 2016. „The Notion of Eurasia: A Spatial, Historical and Political Construct." W Questioning Post-Soviet, red. Edward C. Holland i Matthew Derrick. Washington, D.C.: Wilson Center.

Mahbubani, Kishore. 2008. The New Asian Hemisphere: The Irresistible Shift of Global Power to the East. New York: Public Affairs.

Massey, Doreen. 1991. „A Global Sense of Place.” Marxism Today, 24-29 czerwca.

Mbembe, Achille. 2000. De la postcolonie: Essai sur l'imagination politique dans l'Afrique contemporaine. Paris: Karthala.

Melegh, Attila. 2006. On the East-West Slope: Globalization, Nationalism, Racism and Discourses on Eastern Europe. Budapest: Central European University Press.

Middell, Matthias (red.) 2013. Self-reflexive Area Studies. Leipzig: Leipziger Universitätsverlag.

Mielke, Katja, i Anna-Katharina Hornidge (red.) 2016. Area Studies at the Crossroads: Knowledge Production after the Mobility Turn. Basingstoke: Palgrave Macmillan.

Mignolo, Walter D. 2002. „The Geopolitics of Knowledge and the Colonial Difference." South Atlantic Quarterly 101(1): 57-96. https:// doi.org/10.1215/00382876-101-1-57.

Mignolo, Walter D. 2011. „The Global South and World Dis/order.” Journal of Anthropological Research 67(2): 165-188. https://doi. org/10.3998/jar.0521004.0067.202.

Mignolo, Walter D. 2014a. „The North of the South and the West of the East: A Provocation to the Question." IBRAAZ 8. https://www. ibraaz.org/essays/108/.

Mignolo, Walter D. 2014b. „Spirit out of Bounds Returns to the East: The Closing of the Social Sciences and the Opening of Independent Thoughts." Current Sociology 62(4): 584-602. https://doi. org/10.1177/0011392114524513.

Mikanowski, Jacob. 2017. „Goodbye, Eastern Europe!” Los Angeles Review of Books, 27 stycznia. https://lareviewofbooks.org/article/ goodbye-eastern-europe/.

Miraftab, Faranak. 2009. „Insurgent Planning: Situating Radical Planning in the Global South." Planning Theory 8(1): 32-50. https://doi. org/ 10.1177/1473095208099297.

Miyares, Ines M. 1998. „»Little Odessa« - Brighton Beach, Brooklyn: An Examination of the Former Soviet Refugee Economy in New York City." Urban Geography 19(6): 518-530. https://doi.org/10.2747/02723638.19.6.518. 
Mol, Annemarie, i John Law. 1994. „Regions, Networks and Fluids: Anaemia and Social Topology." Social Studies of Science 24(4): 641671. https://doi.org/10.1177/030631279402400402.

Müller, Martin. 2019. Goodbye Postsocialism! Europe-Asia Studies. in press. Źródło: https://ssrn.com/abstract=3151362.

Neumann, Iver B. 1999. Uses of the Other: "The East" in European Identity Formation. Minneapolis: University of Minnesota Press.

Neumann, Iver B. 2015. „Authoritarian East.” Global Affairs 1(1): 93-94. https://doi.org/10.1080/23340460.2014.960190.

Nowicka, Magdalena. 2017. „»I Don't Mean to Sound Racist but . . . « Transforming Racism in Transnational Europe." Ethnic and Racial Studies 41(5): 824-841. https://doi.org/10.1080/01419870.2017. 1302093.

Outhwaite, William, i Larry Ray. 2005. Social Theory and Postcommunism. Oxford: Wiley.

Parnell, Susan, i Sophie Oldfield (red.) 2014. The Routledge Handbook on Cities of the Global South. London: Routledge.

Parnell, Susan, i Jennifer Robinson. 2012. „(Re)theorizing Cities from the Global South: Looking beyond Neoliberalism.” Urban Geography 33(4): 593-617. https://doi.org/10.2747/0272-3638.33.4.593.

Prashad, Vijay. 2013. The Poorer Nations: A Possible History of the Global South. London: Verso.

Prigogine, Ilya. 1996. La fin des certitudes. Paris: Odile Jacob.

Reuveny, Rafael X., i William R. Thompson. 2007. „The North-South Divide and International Studies: A Symposium." International Studies Review 9(4): 556-564. https://doi.org/10.1111/j.14682486.2007.00722.x.

Rigg, Jonathan. 2007. An Everyday Geography of the Global South. London: Routledge.

Robinson, Jennifer. 2006. Ordinary Cities: Between Modernity and Development. London: Routledge.

Robinson, Jennifer. 2016. „Starting from Anywhere, Making Connections: Globalizing Urban Theory." Eurasian Geography and Economics 57(45): 643-657. https://doi.org/10.1080/15387216.2016.1271617.

Rogers, Douglas. 2010. „Postsocialisms Unbound: Connections, Critiques, Comparisons." Slavic Review 69(1): 1-15. https://doi. org/10.1017/s0037677900016673.

Rose, Gillian. 1993. Feminism and Geography: The Limits of Geographical Knowledge. Minneapolis: University of Minnesota Press.

Roy, Ananya. 2009. „The 21st-century Metropolis: New Geographies of Theory." Regional Studies 43(6): 819-830. https://doi. org/10.1080/00343400701809665. 
Roy, Ananya, i Emma S. Crane. 2015. Territories of Poverty: Rethinking North and South. Athens: University of Georgia Press.

Said, Edward W. 2005. Orientalizm. Tłum. Monika Wyrwas-Wiśniewska. Poznań: Zysk i S-ka.

Schlögel, Karl. 2007. Das russische Berlin: Ostbahnhof Europas. München: Pantheon.

Schueth, Sam. 2011. „Assembling International Competitiveness: The Republic of Georgia, USAID, and the Doing Business Project.” Economic Geography 87(1): 51-77. https://doi.org/10.1111/j.1944-8287.2010.01103.x. Sgibnev, Wladimir. 2015. "Remont: Housing Adaptation as Meaningful Practice of Space Production in Post-Soviet Tajikistan.” Europa Regional 22(1-2): 53-64.

Shields, Rob. 2012. „Cultural Topology: The Seven Bridges of Königsberg, 1736." Theory, Culture \& Society 29(4-5): 43-57. https://doi. org/10.1177/0263276412451161.

Sidaway, James D. 2013. „Geography, Globalization, and the Problematic of Area Studies." Annals of the Association of American Geographers 103(4): 984-1002. https://doi.org/10.1080/00045608.2012 .660397 .

Sidaway, James D., Elaine L. E. Ho, Jonathan D. Rigg, i Chih Y. Woon. 2016. „Area Studies and Geography: Trajectories and Manifesto.” Environment and Planning D: Society and Space 34(5): 777-790. https://doi.org/ 10.1177/0263775816656520.

Smith, Jeremy, i Paul Richardson. 2017. „The Myth of Eurasia - A Mess of Regions." Journal of Borderlands Studies 32(1): 1-6. https://doi. org/10.1080/08865655.2016.1266276.

Spivak, Gayatri C. 2010. „Czy podporządkowani inni mogą przemówić?” Tłum. Ewa Majewska. Krytyka Polityczna 24-25: 196-239.

Spivak, Gayatri C. 1988. „Subaltern Studies: Deconstructing Historiography." W Selected Subaltern Studies, red. Ranajit Guha i Gayatri Chakravorty Spivak. Oxford: Oxford University Press.

Spivak, Gayatri C. 1993. Outside in the Teaching Machine. London: Routledge.

Suslov, Mikhail, i Mark Bassin (red.) 2016. Eurasia 2.0: Russian Geopolitics in the Age of New Media. Lanham: Lexington Books.

Timár, Judit. 2004. „More than »Anglo-American«, It is »Western«: Hegemony in Geography from a Hungarian Perspective." Geoforum 35(5): 533-538. https://doi.org/10.1016/j.geoforum.2004.01.010.

Tlostanova, Madina. 2008. „The Janus-faced Empire Distorting Orientalist Discourses: Gender, Race and Religion in the Russian/(Post) Soviet Constructions of the "Orient«." Worlds and Knowledges Otherwise 2(2): 1-11. 
Tlostanova, Madina. 2011. „The South of the Poor North: Caucasus Subjectivity and the Complex of Secondary "Australism «." The Global South 5(1): 66-84. https://doi.org/10.2979/globalsouth.5.1.66. Tlostanova, Madina. 2015a. „Can the Post-Soviet Think? Intersections.” East European Journal of Society and Politics 2(1): 38-58.

Tlostanova, Madina. 2015b. „Between the Russian/Soviet Dependencies, Neoliberal Delusions, Dewesternizing Options, and Decolonial Drives." Cultural Dynamics 27(2): 267-283. https://doi.org/10.1177/0921374015585230.

Tlostanova, Madina. 2017. Postcolonialism and Postsocialism in Fiction and Art. New York: Palgrave Macmillan.

Todorova, Maria. 2014. Batkany wyobrażone. Tłum. Piotr Szymor i Magdalena Budzińska. Wołowiec: Wydawnictwo Czarne.

Tuvikene, Tauri. 2016. „Strategies for Comparative Urbanism: Post-Socialism as a De-Territorialized Concept." International Journal of Urban and Regional Research 40(1): 132-146. https://doi.org/10.1111/14682427.12333.

Ushkalov, Igor, i Irina Malakha. 2010. Utechka umov. Moscow: Librokom.

Van Schendel, Willem. 2002. „Geographies of Knowing, Geographies of Ignorance: Jumping Scale in Southeast Asia.” Environment and Planning D: Society and Space 20(6): 647-668. https://doi. org/10.1068/d16s.

Wallerstein, Immanuel. 1976. „Semi-Peripheral Countries and the Contemporary World Crisis." Theory and Society 4(3): 461-483. https:// doi.org/10.1007/BF00161293.

Wallerstein, Immanuel. 1979. The Capitalist World Economy. Cambridge: Cambridge University Press.

Wanner, Catherine. 2007. Communities of the Converted: Ukrainians and Global Evangelism. Culture and Society after Socialism. Ithaca, NY: Cornell University Press.

Wolff, Larry. 2020. Wynalezienie Europy Wschodniej: Mapa cywilizacji $w$ dobie oświecenia. Tłum. Maciej Janowski. Kraków: Międzynarodowe Centrum Kultury w Krakowie.

Zarakol, Ayse. 2011. After Defeat: How the East Learned to Live with the West. Cambridge: Cambridge University Press.

Zarycki, Tomasz. 2014. Ideologies of Eastness in Central and Eastern Europe. London: Routledge.

Žižek, Slavoj. 2011. Living in the End Times. London: Verso. 
MARTIN MÜLLER - jest profesorem na Wydziale Geografii i Zrównoważonego Rozwoju na Uniwersytecie w Lozannie, gdzie przewodzi grupie badawczej M3 (Materialities | Multiplicities | Metropolis). http:// igd.unil.ch/martin.muller/en/presentation/.

\section{Dane adresowe:}

University of Lausanne

Faculty of geosciences and environnement

Géopolis 3514

CH-1015 Lausanne

email: martin.muller@unil.ch

Cytowanie: Müller, Martin. 2020. „W poszukiwaniu Globalnego Wschodu: myślenie między Północą a Południem.” Tłum. Anna Piekarska. Praktyka Teoretyczna 3(37): 157-186.

DOI: $10.14746 /$ prt2020.3.8

Finansowanie: Praca ta powstała przy wsparciu Narodowej Fundacji Nauki w Szwajcarii [PP00P1_144699].

Author: Martin Müller

Title: In Search of the Global East: Thinking between North and South Abstract: Carving up the world into Global North and Global South has become an established way of thinking about global difference since the end of the Cold War. This binary, however, erases what this paper calls the Global East - those countries and societies that occupy an interstitial position between North and South. This paper problematises the geopolitics of knowledge that has resulted in the exclusion of the Global East, not just from the Global North and South, but from notions of globality in general. It argues that we need to adopt a strategic essentialism to recover the Global East for scholarship. To that end, it traces the global relations of IKEA's bevelled drinking glass to demonstrate the urgency of rethinking the Global East at the heart of global connections, rather than separate from them. Thinking of such a Global East as a liminal space complicates the notions of North and South towards more inclusive but also more uncertain theorising.

Keywords: Global North, Global South, Second World, postcolonialism, postsocialism, post communism, geopolitics of knowledge 